\title{
Yellow passion fruit rind (Passiflora edulis): an industrial waste or an adjuvant in the maintenance of glycemia and prevention of dyslipidemia?
}

\author{
Sandra Maria Barbalho ${ }^{1,2 *}$, Maricelma da Silva Soares de Souza', Júlio César de Paula e Silva ${ }^{3}$, Claudemir Gregório Mendes ${ }^{1}$, \\ Gabriela Aparecida de Oliveira', Tainara Costa² and Flávia M. V. Farinazzi-Machado²
}

\begin{abstract}
The use of plants for the treatment of many disorders is a common practice in Brazil, especially for raw consumption and processed juice. The scientific community has shown increasing interest in these plants due to their phytotherapeutic properties. The aim of this study was to evaluate the biochemical profile (glucose, total cholesterol, HDL-c, LDL-c and triacylglycerol) of male Wistar rats treated with extract of Passiflora edulis rind. The rats were divided into two groups ( $\mathrm{n}=15 /$ group) dubbed the GC/control group and the GT/ treated group. The intake of Passiflora edulis rind powder consisted of twice daily gavage feeding for 30 consecutive days. The values of the biochemical parameters of glucose, total cholesterol and HDL-c differed statistically. It was found that P. edulis can be helpful in controlling total cholesterol and increasing HDL-c levels.
\end{abstract}

keywords: Passiflora edulis rind, HDL-c, cholesterol, glycemia.

\section{Background}

Plants have been used throughout history for the treatment of a variety of disorders. Although not always scientifically confirmed, this practice still widely used today to treat numerous different diseases. These include diabetes and dyslipidemias, which represent risk factors for the development of other disorders such as cardiovascular diseases (CVD) [1,2].

Diabetes and CVD are among the most prevalent diseases in the modern world and also the ones with the highest morbimortality. The former disease is characterized by hyperglycemia due to total, partial or relative insulin deficiency, which alters the metabolism of carbohydrates, proteins, lipids and mineral salts. Hyperglycemia and dyslipidemia are risk factors for the development of hypertension and CVD [3-6].

The genus Passiflora (passion fruit) is one of the most well known of the various phytotherapeutic plants used by the population. This plant belongs to the family Passifloracea, with originated in the tropical and subtropical regions of the American continent and is abundant in Brazil. The species of this genus are well known for their effects on the central nervous system (to treat anxiety), insomnia, and for their analgesic, antispasmodic and anti-inflammatory activities [7-12].

Brazil is the largest producer of this fruit, with more than 35 thousand hectares under cultivation and an annual production in excess of 317 thousand tons. The fruit juice industry uses

\footnotetext{
*Correspondence: smbarbalho@terra.com.br

'Department of Biochemistry and Pharmacology (UNIMAR, Marília - SP);

${ }^{2}$ Department of Biochemistry and Nutrition

(Faculty of Food Technology of Marília (FATEC) - SP). Brazil.

Full list of author's information is available at the end of the article
}

approximately $30 \%$ of the total mass of the fruits. The remainder is classified as industrial waste. However, this waste contains high amounts of substances indispensable to human nutrition in the form of fibers, vitamins, mineral salts, phenolic compounds and flavonoids, which could be utilized for the preparation of new products. Passion fruit rind is composed of the epicarp or flavedo (colored part) and the mesocarp or albedo (the white portion), which is rich in fibers and is a source of iron, calcium, phosphorus and niacin [13-16].

The literature contains only two studies that used powdered rind of the species $P$. edulis in human diabetics $[8,17]$.

The use of phytotherapy has been growing, but it should be kept in mind that to achieve a safe therapeutic outcome, the production of these plants necessarily requires previous studies about their botanical, agronomic, phytochemical, pharmacological and toxicological aspects. Moreover, the results presented in such studies must be reproducible. In this context, the use of passion fruit rind not only represents a therapeutic prospect for CVD risk factors but also contributes to reduce the amount of waste produced by the fruit juice industry, which is also a highly positive factor for the environment. In view of these facts, the present work aimed to evaluate the effect of passion fruit rind on the biochemical profile of Wistar rats.

\section{Methods}

\section{Animals and ethical aspects}

The experiments involved the use of Wistar rats weighing approximately $250 \mathrm{~g}$ supplied by the Center for Animal Model Experimentation (CEMA) of the University of Marilia (UNIMAR). The animals were housed in a vivarium under a 12/12-hour light/ dark cycle at an ambient temperature of $22 \pm 2^{\circ} \mathrm{C}$, a cycle and

(C) 2012 Barbalho et al; licensee Herbert Publications Ltd. This is an open access article distributed under the terms of Creative Commons Attribution License

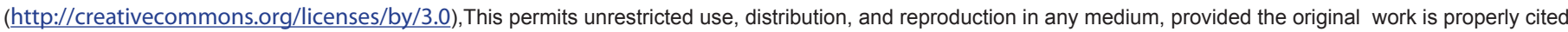


relative humidity of $60 \pm 5 \%$, and were fed and watered ad libitum. They were treated according to the "Guide to the care and use of experimental animals", which outlines the principles of the Canadian Council on Animal Care for laboratory animals.

The rats were divided into two groups ( $\mathrm{n}=15$ per group): a control group (CG), which received water, and a treatment (TG), which received Passiflora edulis extract. The amount of ration and volume of water ingested were checked daily.

This project was approved by the University of Marilia Research Ethics Committee (N. 226) from the ethical standpoint and was in line with current legislation, particularly Federal Laws Nos. 6638 of May 8, 1979 and 9605 of February 12, 1998.

Preparation of the extract and treatment of the animals. The passion fruit was purchased from the Farming Cooperative of Lins, SP, Brazil (COALINS).

The passion fruit rinds (epicarp and mesocarp) were washed, weighed and dehydrated on trays in a forced air circulation drying oven at $55^{\circ} \mathrm{C}$ until they reached a constant dry weight [18]. They were then ground into powder in a multiprocessor. Each grinding run was made with 200 grams of rind and ground for a total of 6 minutes, turning off the processor at 2 minute intervals to stir the product with a plastic spatula.

A solution was then prepared consisting of $20 \mathrm{~g}$ of powdered rind and $500 \mathrm{~mL}$ of water, which was beaten in a blender for 12 minutes and then filtered through filter paper. The resulting solution was divided into aliquots, which were stored in a freezer at $-10^{\circ} \mathrm{C}$ until the moment they were administered.

The extract ingestion program consisted of gavage feeding twice daily (morning and afternoon, always at the same time and with an interval of 10 hours) for 30 consecutive days. The concentration administered was $1 \mathrm{~mL}$ of the prepared passion fruit solution per kilogram of weight. The animals were weighed weekly and the volume of extract adjusted accordingly.

Collection of blood samples for the biochemical profile. After 30 days of treatment, blood samples were collected by exsanguination after anesthetizing the animals with sodium pentobarbital (the blood was collected by puncture of the vena cava). The blood was then processed to obtain serum, which was analyzed using commercial kits to check for glycemia, total cholesterol, LDL-c, HDL-c and triglycerides (kit LABTEST ${ }^{\circ}$ for total cholesterol, HDL-c and e triglycerides and WIENER $\mathrm{LAB}^{\circ}$ for $\left.\mathrm{LDL}-\mathrm{c}\right)$. The data were analyzed based on mean values, standard deviation, and statistical testing.

Table 1. Body weight (g) from control group and group treated with P. edulis rind before (time 1) and after treatment (time 2).

\begin{tabular}{llll}
\hline & \multicolumn{2}{c}{ Groups } & p-value \\
\cline { 2 - 3 } & Control & P. edulis & \\
\hline Body weight (time 1) & $246,9 \pm 42,7$ & $263,3 \pm 39,3$ & 0.0898 \\
Body weight (time 2) & $425,3 \pm 29,7$ & $305,9 \pm 38,8$ & 0.0059 \\
p-value & 0.0067 & 0.0089 & \\
\hline
\end{tabular}

Values presented as mean \pm standard deviation (SD).

\section{Statistical analysis}

The variables are presented as means and standard deviations. The data were analyzed by Tukey-test with a 5\% level of significance.

\section{Results \& discussion}

An analysis of Table 1 indicates that there were significant differences in body weight after the use of the passion flower rind. Animals from control and treated group did not present significant differences in body weigh before the intervention, but they showed significant higher values when compared to the treated group after treatment.

Modifications in lifestyle and diet are major contributors for the high prevalence of obesity. Overweight and obesity are commonly associated with different risk factors to the development of diabetes, cardiovascular diseases and cancer. These findings have been confirmed in several clinical studies involving human and animal models, which found hyperglycemia and augmented levels of total cholesterol, triglycerides and LDL-c and reduced $\mathrm{HDL}-\mathrm{c}$ levels associated with overweigh. Increases lipid levels are also risk factors for cardiovascular diseases. They are involved in the accumulation of lipids in the liver and are implicated in the development of type 2 diabetes and its correlated risks, such as metabolic syndrome. The consumption of healthy foods can prevent the development of these risk factors and can, as well, prevent diabetes and heart diseases [18-23]. Ramos et al [8] used passion fruit peel flour in human volunteers and observed reduction in body weight. They attributed this result to the presence of pectin. The flour of the passion fruit peel is rich in this kind of soluble fiber.

Table 2 indicates that LDL-c levels did not vary significantly, but HDL-c levels increased significantly. Glycemia, triglycerides and total cholesterol levels decreased in animals treated with passion fruit rind when compared with the control group.

Ramos et al [8] used passion fruit rind in the form of flour on type 2 diabetes mellitus patients and observed a reduction in the LDL-c and total cholesterol levels but detected no change in glycemia and $\mathrm{HDL}-\mathrm{c}$ levels (they did not evaluate triglyceride levels). Janebro et al. [17] also used passion fruit flour on type 2 diabetes mellitus patients, but, unlike Ramos

Table 2. Biochemical profile $(\mathrm{mg} / \mathrm{mL})$ from control group and group treated with P. edulis rind.

\begin{tabular}{llll}
\hline & \multicolumn{2}{c}{ Groups } & \multirow{2}{*}{ p-value } \\
\cline { 2 - 3 } & Control & P. edulis & \\
\hline Glucose & $136,5 \pm 21,6$ & $86,4 \pm 20,4$ & 0.0048 \\
Cholesterol & $203,3 \pm 43,9$ & $116,9 \pm 16,3$ & 0.0069 \\
Triglycerides & $83,8 \pm 29,3$ & $60,3 \pm 33,9$ & 0.00701 \\
HDL-c & $19,6 \pm 5,4$ & $46,8 \pm 17,7$ & 0.0055 \\
LDL-c & $131,9 \pm 25,2$ & $122,4 \pm 20,4$ & 0.0693 \\
\hline
\end{tabular}

Values presented as mean \pm standard deviation (SD). 
et al. [8], they did not find a reduction in cholesterol and LDL-c but observed a reduction in glycemia (they also reported a reduction in triglyceride levels and increase in $\mathrm{HDL}$-c levels). Other studies have shown that other parts of the passion fruit can also have beneficial effects on lipid and glycemic profiles [24]. The effects obtained with the use of rind may be attributed to the presence of fibers. Passion fruit rind is rich in soluble fibers such as pectins and mucilage. According to Yapo, Koff [25], 73\% of the dry matter in the species P. edulis is in the form of fiber, $60 \%$ of which is insoluble fiber. Pectin is able to retain water, forming viscous gels that delay gastric voiding and bowel transit times, which are factors that reduce hunger, and thus reduce overweight/obesity. Moreover, these gels can reduce plasma levels of total cholesterol, triglycerides and $\mathrm{LDL}-\mathrm{c}$ and increase HDL-c levels. This is possibly because the presence of fibers increases the excretion of cholesterol and biliary salts in the feces. Therefore, the consumption of fibers may reduce the risks for diseases such as diabetes, dyslipidemias, obesity and CVD [26-31]. Chau, Huang [32] used $P$. edulis seed fibers and observed beneficial effects on the lipid profile of hamsters.

Janebro et al. [17] associated the reduction in glycemia and the improvement in HDL-c and triglycerides levels to the supplementation of diet with soluble dietary fiber found in the rinds that can be considered an important therapy measure in the treatment of diabetic and obese patients. Silva et al. [14] also found that pectin from P. edulis decreased blood glucose and triglyceride levels in diabetic rats and concluded that this fiver has potential as a useful alternative treatment for type 2 diabetes and that its anti-inflammatory properties are probably involved in its antidiabetic action.

The presence of antioxidants, vitamins and flavonoids in passion fruit (C-glycosyl flavonoids are the main components of Passiflora species) is related to important effects in the maintenance of glycemia and plasma lipids. Among the compounds with antioxidant and antiinflammatory effects found in passion fruit species are chlorogenic acid, hyperoside, isovitexin, caffeic acid, quercetin, luteolin, orentin, rutin, vitexin and others [15,33-38]. The presence of these compounds may also explain the beneficial effects of $P$. edulis on glycemia and on plasma lipids observed in this study.

The classical known risk factors include high levels of LDL-C and low levels of $\mathrm{HDL}-\mathrm{c}$, which are implicated with an important increase in the incidence of atherosclerotic cardiovascular disease. A therapeutic target that has aroused much interest is the increase in $\mathrm{HDL}$-c levels, since low levels of this fraction of cholesterol constitute the lipid abnormality most frequently found in CVD patients. Some studies have demonstrated that increased levels of serum HDL-c in the order of $1 \mathrm{mg} / \mathrm{dL}$ lead to a reduction of $2 \%-3 \%$ in the incidence of CVD. It has also been demonstrated that high levels of HDL-c can prevent the progression of atherosclerotic plaque, promoting its regression [39]. The use of powdered Passiflora rind proved to play an important role in raising the levels of HDL-c in the blood of the animals used in this study, indicating that its use may be beneficial to increase this lipoprotein. Furthermore, passion fruit rinds are discarded by fruit juice processing plants and constitute an important source of industrial waste that is available in large quantities. Therefore, the use of this waste to produce new functional products may be attractive for the food industry.

\section{Conclusion}

The results of this work indicate that the use of passion fruit rinds contributed significantly to control the biochemical variables and body weight of the experimental model under study. So, its use can work as an adjuvant in the treatment of disorders of the glycemic and lipid profile, reducing risk factors for death by cardiovascular diseases, and also serving to reduce industrial wastes and hence environmental pollution.

\section{Competing interests}

Authors declare no conflict of interests.

\section{Author's contribution}

All authors contributed with all parts of the research and writing the manuscript.

\section{Author's information}

${ }^{3}$ FUNDECIF (Foundation to the development of Pharmaceutical Sciences) - UNESP, Araraquara - SP / Brazil.

\section{Publication history}

Received: 17-May-2012 Revised: 20-June-2012

Accepted: 03-July-2012 Published: 14-July-2012

\section{References}

1. Snel M, Gastaldelli A, Ouwens DM, Hesselink MK, Schaart G, Buzzigoli $E$, et al.: Effects of adding exercise to a 16-week very low-calorie diet in obese, insulin-dependent type 2 diabetes mellitus patients. J Clin Endocrinol Metab 2012; 97;(7.);2512-20. I Article I PubMed

2. Chen G, McAlister FA, Walker RL, Hemmelgarn BR, Campbell NR: Cardiovascular outcomes in framingham participants with diabetes: the importance of blood pressure. Hypertension 2011; 57;(5.);891-7. | Article | PubMed

3. Jee $\mathrm{SH}$, Jo J: Linkage of epidemiologic evidence with the clinical aspects of metabolic syndrome. Korean Circ J 2012; 42;(6.);371-8. | Article | PubMed

4. Robins JL, McCain NL, Elswick RK: Exploring the complexity of cardiometabolic risk in women. Biol Res Nurs 2012; 14;(2.);160-70. | Article I PubMed

5. Bowden DW, Cox AJ, Freedman BI, Hugenschimdt CE, Wagenknecht LE, Herrington D, et al.: Review of the Diabetes Heart Study (DHS) family of studies: a comprehensively examined sample for genetic and epidemiological studies of type $\mathbf{2}$ diabetes and its complications. Rev Diabet Stud 2010; 7;(3.);188-201. | Article | PubMed Abstract | PubMed Full Text

6. Ratner R, Han J, Nicewarner D, Yushmanova I, Hoogwerf BJ, Shen L: Cardiovascular safety of exenatide BID: an integrated analysis from controlled clinical trials in participants with type 2 diabetes. Cardiovasc Diabetol 2011; 10;(22). I Article I PubMed Abstract | PubMed Full Text

7. Doyama JT, Rodrigues HG, Novelli EL, Cereda E, Vilegas W: Chemical investigation and effects of the tea of Passiflora alata on biochemical parameters in rats. J Ethnopharmacol 2005; 96;(3.);371-4. | Article | PubMed 
8. Ramos AT, Cunha MAL, Sabaasrur AUO, Pires VCF, Cardoso AA et al. Use of Passiflora edulis f. flavicarpa on cholesterol reduction. Braz J Pharma$\operatorname{cog}$ 2007;17: 592-560. | Article

9. Deng J, Zhou Y, Bai M, Li H, Li L: Anxiolytic and sedative activities of Passiflora edulis f. flavicarpa. J Ethnopharmacol 2010; 128;(1.);148-53. | Article | PubMed

10. Sato AC, Andrade SA, Brito MV, Miranda A, Sampaio MU, de Abreu Maffei FH, et al.: Effects of compounds from Passiflora edulis Sims f. flavicarpa juice on blood coagulation and on proteolytic enzymes. Protein Pept Lett 2012; 19;(5.);501-8. | Article | PubMed

11. Ngan A, Conduit R: A double-blind, placebo-controlled investigation of the effects of Passiflora incarnata (passionflower) herbal tea on subjective sleep quality. Phytother Res 2011; 25;(8.);1153-9. | Article | PubMed

12. Fiebich BL, Knorle R, Appel K, Kammler T, Weiss G: Pharmacological studies in an herbal drug combination of St. John's Wort (Hypericum perforatum) and passion flower (Passiflora incarnata): in vitro and in vivo evidence of synergy between Hypericum and Passiflora in antidepressant pharmacological models. Fitoterapia 2011; 82;(3.);474-80. | Article | PubMed

13. Farid R, Rezaieyazdi Z, Mirfeizi Z, Hatef MR, Mirheidari M, Mansouri H, et al.: Oral intake of purple passion fruit peel extract reduces pain and stiffness and improves physical function in adult patients with knee osteoarthritis. Nutr Res 2010; 30;(9.);601-6. | Article | PubMed

14. Silva DC, Freitas AL, Pessoa CD, Paula RC, Mesquita JX, Leal LK, et al.: Pectin from Passiflora edulis shows anti-inflammatory action as well as hypoglycemic and hypotriglyceridemic properties in diabetic rats. J Med Food 2011; 14;(10.);1118-26. I Article I PubMed

15. Zucolotto SM, Fagundes C, Reginatto FH, Ramos FA, Castellanos L, Duque C, et al.: Analysis of C-glycosyl flavonoids from South American Passiflora species by HPLC-DAD and HPLC-MS. Phytochem Anal 2012; 23;(3.);232-9. I Article I PubMed

16. do Espirito Santo AP, Cartolano NS, Silva TF, Soares FA, Gioielli LA, Perego $P$, et al.: Fibers from fruit by-products enhance probiotic viability and fatty acid profile and increase CLA content in yoghurts. Int J Food Microbiol 2012; 154;(3.);135-44. | Article | PubMed

17. Janebro D I, Queiroz M S R, Ramos A T, Sabaa-Srur A U O, Cunha MAL, Diniz M F. Effect of the flour of the yellow passion fruit peel (Passiflora edulis f. flavicarpa Deg.) in the glycemic and lipid levels of type $\mathbf{2}$ diabetes patients. Rev Bras Farmacog 2008;18: 723-732. | Article

18. Soriguer F, Rojo-Martinez G, Valdes S, Tapia MJ, Botas P, Morcillo S, et al.: Factors determining weight gain in adults and relation with glucose tolerance. Clin Endocrinol (Oxf) 2012. | Article | PubMed

19. Arcidiacono B, liritano S, Nocera A, Possidente K, Nevolo MT, Ventura V, et al.: Insulin resistance and cancer risk: an overview of the pathogenetic mechanisms. Exp Diabetes Res 2012; 2012;(789174). | Article | PubMed Abstract | PubMed Full Text

20. Chiou WK, Hwang JS, Hsu KH, Lin JD: Diabetes mellitus increased mortality rates more in gender-specific than in nongender-specific cancer patients: a retrospective study of 149,491 patients. Exp Diabetes Res 2012; 2012;(701643). | Article | PubMed Abstract | PubMed Full Text

21. Medeiros F, Casanova Mde A, Fraulob JC, Trindade M: How can diet influence the risk of stroke? Int J Hypertens 2012; 2012;(763507). I Article | PubMed Abstract | PubMed Full Text

22. Gooda Sahib N, Saari N, Ismail A, Khatib A, Mahomoodally F, Abdul Hamid A: Plants' metabolites as potential antiobesity agents. ScientificWorldJournal 2012; 2012;(436039). | Article | PubMed Abstract | PubMed Full Text

23. Roh C, Jung U: Screening of crude plant extracts with anti-obesity activity. Int J Mol Sci 2012; 13;(2.);1710-9.. | Article | PubMed | PubMed Full Text

24. Barbalho SM, Damasceno DC, Spada AP, Lima IE, Araujo AC, Guiguer EL, et al.: Effects of Passiflora edulis on the metabolic profile of diabetic Wistar rat offspring. J Med Food 2011; 14;(12.);1490-5. | Article | PubMed
25. Yapo BM, Koffi KL: Dietary fiber components in yellow passion fruit rind--a potential fiber source. J Agric Food Chem 2008; 56;(14.);5880-3. | Article | PubMed

26. Galisteo M, Duarte J, Zarzuelo A: Effects of dietary fibers on disturbances clustered in the metabolic syndrome. J Nutr Biochem 2008; 19;(2.);7184. | Article | PubMed

27. Hur SJ, Lim BO, Park GB, Joo ST: Effects of various fiber additions on lipid digestion during in vitro digestion of beef patties. J Food Sci 2009; 74;(9.);C653-7. I Article I PubMed

28. Metzger BT, Barnes DM, Reed JD: A comparison of pectin, polyphenols, and phytosterols, alone or in combination, to lovastatin for reduction of serum lipids in familial hypercholesterolemic swine. J Med Food 2009; 12;(4.);854-60. | Article | PubMed

29. Wu SC, Wu SH, Chau CF: Improvement of the hypocholesterolemic activities of two common fruit fibers by micronization processing. J Agric Food Chem 2009; 57;(12.);5610-4. | Article I PubMed

30. Thornton SN: Letter by Thornton regarding article, "Whole-grain, cereal fiber, bran, and germ intake and the risks of all-cause and cardiovascular disease-specific mortality among women with type 2 diabetes mellitus". Circulation 2011; 123;(9.);e265. | Article I PubMed

31. Gardner AW, Bright BC, Ort KA, Montgomery PS: Dietary intake of participants with peripheral artery disease and claudication. Angiology 2011; 62;(3.);270-5. | Article I PubMed

32. Chau CF, Huang YL: Characterization of passion fruit seed fibres-a potential fibre source. Food Chemistry 2004; 85;(2.);189-94. | Article

33. Schreckinger ME, Lotton J, Lila MA, de Mejia EG: Berries from South America: a comprehensive review on chemistry, health potential, and commercialization. J Med Food 2010; 13;(2.);233-46. | Article | PubMed

34. Sunitha M, Devaki K: Antioxidant Activity of Passiflora edulis Sims Leaves. Indian J Pharm Sci 2009; 71;(3.);310-1. I Article I PubMed Abstract | PubMed Full Text

35. Zucolotto SM, Goulart S, Montanher AB, Reginatto FH, Schenkel EP, Frode TS: Bioassay-guided isolation of anti-inflammatory C-glucosylflavones from Passiflora edulis. Planta Med 2009; 75;(11.);1221-6. | Article | PubMed

36. Masteikova R, Bernatoniene J, Bernatoniene R, Velziene S: Antiradical activities of the extract of Passiflora incarnata. Acta Pol Pharm 2008; 65;(5.);577-83. | Article | PubMed

37. Cravotto G, Boffa L, Genzini L, Garella D: Phytotherapeutics: an evaluation of the potential of 1000 plants. J Clin Pharm Ther 2010; 35;(1.);1148. | Article | PubMed

38. Li H, Zhou P, Yang Q, Shen Y, Deng J, Li L, et al.: Comparative studies on anxiolytic activities and flavonoid compositions of Passiflora edulis 'edulis' and Passiflora edulis 'flavicarpa'. J Ethnopharmacol 2011; 133;(3.);1085-90. I Article I PubMed

39. Shang Q, Liu Z, Chen K, Xu H, Liu J: A systematic review of xuezhikang, an extract from red yeast rice, for coronary heart disease complicated by dyslipidemia. Evid Based Complement Alternat Med 2012; 2012;(636547). | Article | PubMed Abstract | PubMed Full Text 